\title{
EVALUATION OF ALTERNATIVE PRE-EMERGENCE HERBICIDES TO ATRAZINE FOR WEED CONTROL ON MAIZE (Zea maysL.) Plot In OGBOMOSO, SOUTHWEST NIGERIA
}

\author{
Olabode O.S. ${ }^{1}$, Oladapo O.S. ${ }^{2}$, Ogunsola A. ${ }^{1}$ and Sangodele A.O. ${ }^{*}$ \\ ${ }^{1}$ Department of Crop Production and Soil Science, Ladoke Akintola University of \\ Technology, LAUTECH, Ogbomoso, Nigeria.
}

${ }^{2}$ Dept of Crop Production, Oyo State College of Agriculture of Technology, Igboora, Nigeria.

*Corresponding author email: deleopeola@gmail.com

Cite this article:

Olabode O.S., Oladapo O.S., Ogunsola A., Sangodele A.O. (2021), Evaluation of Alternative Pre-emergence Herbicides to Atrazine for Weed Control on Maize (Zea maysL.) plot in Ogbomoso, Southwest Nigeria. African Journal of Agriculture and Food Science 4(4), 40-45. DOI: $10.52589 / A J A F S-$ VESP73B1.

\section{Manuscript History \\ Received: 7 Nov 2021 \\ Accepted: 29 Nov 2021 \\ Published: 4 Dec 2021}

Copyright $\odot 2020$ The Author(s). This is an Open Access article distributed under the terms of Creative Commons AttributionNonCommercial-NoDerivatives 4.0 International (CC BY-NC-ND 4.0 ), which permits anyone to share, use, reproduce and redistribute in any medium, provided the original author and source are credited.
ABSTRACT: Field experiments were carried out at the Teaching and Research Farm of the LadokeAkintola University of Technology, (LAUTECH), Ogbomoso to evaluate the effectiveness and determine the optimum rate of applying alternative herbicides to atrazine on maize plots in view of the current criticism against the herbicide. Five herbicides, namely; 3-maize force, Xtra force, Pre-maize Guard force (solution and pellet) at two rates (100\% and $50 \%$ recommended rates) were compared with atrazine at full dose and 3 hoe-weeding in a Randomized complete Block Experiment with 3 replications. Maize, Variety OBA Super, maturing in 75 days, was planted at two plants per stand at a spacing of $75 \times 50 \mathrm{~cm}$ in two-year trials and maintained following the standard procedures. The herbicides were applied using a knapsack sprayer calibrated to deliver at 200liters/ha. Results showed that there were no significant differences $(p=0.05)$ among the treatment and between the treatments and control with respect to seed germination, plant survival and other growth parameters. The highest grain yield $(6757.3 \mathrm{~kg} / \mathrm{ha})$ obtained with atrazine was not significantly different from those of other treatments and control. The effectiveness of the herbicides, measured using weed density and biomass, showed comparable effectiveness across the herbicides and atrazine. Furthermore, at a dosage of 50\%, the herbicide's effectiveness was highly comparable to those of atrazine at $100 \%$. The implications of these findings were discussed.

KEYWORDS: Atrazine, 3-maize force, Xtra force, Premaiz and Guard force. 


\section{INTRODUCTION}

Maize (Zeamay L.) is the third most important cereal crop worldwide after wheat and rice. It provides valuable raw materials for various agro-based industries in addition to its common usage as food for man, bakery products, forages and feed for livestock (Huma et al., 2019). Besides many other factors limiting maize grain yield, weed infestation is a major constraint, reducing the growth and subsequently, the yield of the crop. Weeds had been reported to lower the yield of maize by 24-83\%, (Usman et al., 2001, Ashiq et al., 2003, Jogan et al., 2004), depending on weed type, season and variety. Weeds interfere with maize growth and yield through allelopathy and competition with the consequence of lowered yield quality and quantity (Gupta, 2004).

\section{LITERATURE/THEORETICAL UNDERPINNING}

From the foregoing, control of weeds on maize plots is very essential if a good harvest is expected. The use of mechanical methods for weed control had been criticized for drudgery, soil compaction and mechanical damage to crops amongst other criticisms (Akobundu, 1987). Thus, the advent of the chemicals (herbicides) for weed control in crop production was a welcomed innovation. However, the problems of herbicides ranging from cost, pollution, suitability and technical know-how among the users are worrisome.

The problems of pollution and other hazardous attributes of the use of herbicide had continued to generate disagreement among the consumers (Olabode, 2010). Nonetheless, some popular and effective herbicides have been labelled unfit for use. Atrazine (1-chloro, 3-ethylamino-5isopropylamino 2,4,6 triazine), a pre-emergence herbicide used for effective weed control in maize, is one of such herbicides whose continued use is under criticism for its reported harmful effects on both soil microbial populations as well as other harmful effects on lives in water bodies (Olabode et al., 2010). However, in spite of these, a survey conducted by Olabode et al., (2011) confirmed that atrazine still remained one of the most popular agrochemicals in Nigerian agriculture. Thus, it is imperative that, for the use of atrazine to be curtailed in Nigeria, there is the need for equally effective, easily handled and readily available alternatives. Aside from this, research has shown that persistent use of the same herbicide over a long period tends to give rise to the emergence of weed species that are resistant to such herbicides (Paradowski, 2008; Green and Owen, 2011).

Arising from the above, it has thus become imperative to evaluate alternative herbicides as a substitute/replacement for atrazine. This experiment was, therefore, designed to evaluate the effectiveness and also determine the optimum rate of application of such alternative herbicides and compare the same with atrazine on maize plot.

\section{MATERIALS AND METHODS}

The field experiment was conducted at the Teaching and Research Farm of Ladoke Akintola University of Technology, Ogbomoso, Oyo State, Nigeria, during the rainy seasons of 2018 and 2019 Ogbomoso Oyo State, Nigeria is in the Guinea savanna region and located on latitude $8^{0} 10^{1} \mathrm{~N}$ and longitude $4^{0} 10^{1} \mathrm{E}$. The minimum temperature is about $280^{0} \mathrm{C}$ and the maximum 
temperature is $330^{\circ} \mathrm{C}$ with the humidity being about $74 \%$. The annual rainfall is between $150 \mathrm{~mm}-1250 \mathrm{~mm}$. The rainfall is bimodal with the peaks of rainfall in June and September. The experimental design was a Randomized Complete Block with twelve (12) treatments replicated three times. There were 36 beds each measuring $3 \mathrm{~m}$ by $3 \mathrm{~m}$ and separated by a spacing of $2 \mathrm{~m}$. A 2-metre space also separated the replicates. The treatments were: Xtraforce (Atrazine 250g/l + Metolachlor 250g/l) 3-maize force (metolachlor 375g/L + terbuthylazine $125 \mathrm{~g} / \mathrm{l}$ +mesotrione 37.5g/l),Premaiz (Acetolachlor 447/1 +terbuthylazine 215g/L), Guard force (Nicosulfuron 40g/l) (Pellets \& Solution), Atrazine and hoe weeding. All the herbicides except atrazine were each applied at $100 \%$ and $50 \%$ of the recommended rates while atrazine which together with the hoe weeding were the control treatment, was applied at a recommended rate only(Table 1). There were 3 hoe weedings at 2,4 and 6 weeks after planting (WAP). The herbicides were applied pre/post emergently as recommended by the respective manufacturers. Herbicide application is done using a knapsack sprayer model Cp18 which delivers at 200litres per hectare.

Maize, var OBA Super, a 75days variety was planted on the 15th and 17th of June 2018 and 2019 respectively on flats at a spacing of $75 \mathrm{~cm} \times 50 \mathrm{~cm}$ at 2 plants per stand giving 53,333 plants per hectare. Five (5) grams of WPK 15-15-15 was applied twice per stand at 3WAP, as a starter dose, and topped up at tasselling. Rogueing was carried out at tasselling to argue the control methods.

Data were collected on percentage germination at 8days after planting (DAP), percentage survival at 15DAP, plant height (using metre rule), stem diameter (using vernier calliper) and leaf area all at tasselling.

The yield parameters measured include the number of seeds per Cob, the weight of seeds per Cob (g) weight of 100 seeds (g) and estimated seed yield ( $\mathrm{kg} / \mathrm{ha})$. Data were also collected on weed density (units $/ 0.5 \mathrm{~m}^{2}$ ) and biomass $\left(\mathrm{g} / 0.5 \mathrm{~m}^{2}\right)$ using the quadrat method. Mean data collected over the two years were subjected to the relevant analysis of variance (ANOVA) and means were compared using the Duncan's Multiple Range Test (DMRT) at 5\% of probability.

\section{RESULTS/FINDINGS}

The major weeds encountered on the plot were Tithoniadiversifolia, Euphorbia heterophylla, Rottboelliacochinchinensis, Tridaxprocumbensand someCommelinabenghalensis. The effect of the herbicides on the germination and growth of maize is presented in Table 2. Herbicides' application had no significant effect on maize germination. Similarly, there was no significant $(\mathrm{P}=0.05)$ effect of herbicides' application across the rates on the survival rate of maize seedlings. The plant height of maize was also not affected by any of the herbicides treatment at tasselling. There was no significant difference between the treated maize and the hoe weeding control concerning these parameters. Plant survival ranged between $80 \%$ and $92 \%$ while plant height ranged from $59.4 \mathrm{~cm}$ to $71.3 \mathrm{~cm}$. Maize stem diameter and leaf area were similarly not influenced by the treatments.

The result of maize yield as influenced by the herbicides' treatment is shown in Table 3 . The number of seeds per cob, the weight of seed per cob $(\mathrm{g})$ and the weight of 100 seeds $(\mathrm{g})$ were all not statistically different $(\mathrm{P}=0.05)$ from the hoe weeding control treatment. The estimated seed yield $(\mathrm{kg} / \mathrm{ha})$ as presented in Table 3 showed that atrazine with $6757.3 \mathrm{~kg}$ gave the highest 
yield which was however not superior to other treatments except Guard force pellet at 50\% (5136.0kg) and Premaiz at 50\% (4709.3kg).

The weed control effectiveness of the tested herbicides is presented in Table 4. The highest weed density $\left(5.4 / 0.5 \mathrm{~m}^{2}\right)$ was recorded in the two Guard force products treatments which were similar to those of the hoe weeding control plot $\left(6.0 / 0.5 \mathrm{~m}^{2}\right)$. Weed densities on other plots ranged from 4.0-4.6 and were not significantly different $(\mathrm{P}=0.05)$ from those of atrazine. The weed biomass recorded from the treated plots was highest on the guard force solution treated plot at a concentration of $50 \%\left(170 \mathrm{~g} / 0.5 \mathrm{~m}^{2}\right)$. This value was similar to those obtained on plots treated with Premaiz at $50 \%$ of the recommended dose $\left(107 \mathrm{~g} / 0.5 \mathrm{~m}^{2}\right)$. The weed biomass across other treatments were all comparable to those of atrazine at $100 \%$ and Hoe weeding.

\section{DISCUSSION}

The tested herbicides and their application rates had no significant effect on the germination and survival rate of maize since they are indicated for weed control in maize. Very good vegetative growth and grain yield observed on the treated plots which compared very favourably with those on atrazine and hoe weeded plots is a testimony of the effectiveness of the herbicides in weed control which minimized weed-crop competition (Olabode et al., 2010; Ogungbile and Lagoke, 1986). The effectiveness of low dosage of the evaluated herbicides is also a welcome development at reducing the rate of pollution and cost of production. Olabode et al. (2008 \&2010) had reported similar findings with primextra and atrazine.

\section{CONCLUSION}

From the result of the present study, it is evident that the tested herbicides compared favourably with atrazine in both weed control and crop yield. Besides, the effectiveness of the reduced dosage of the herbicides makes them candidate herbicides for replacing atrazine which is being touted as a pollutant. Furthermore, these herbicides will likely tend to check the ever-increasing cost of atrazine due to a hitherto non-availability of competent alternatives. The resultant possible reduction in production cost is likely to enhance maize farmers' net income, thereby inducing higher production.

Table 1: Treatment table.

\begin{tabular}{lll}
\hline \multicolumn{1}{c}{ Herbicides } & \multicolumn{1}{c}{$\%$ Dose Used } & Recommended dose (1/ha) \\
\hline Xtra force & 100,50 & 3.0 \\
3-maize force & 100,50 & 3.0 \\
Pre maize & 100,50 & 3.0 \\
Guard force (Solution) & 100,50 & 3.0 \\
Guard force (Pellets) & 100,50 & $3.0(\mathrm{~kg} / \mathrm{ha})$ \\
Atrazine & 100 & 3.0 \\
Hoe weeding (3 times) & & 3 times \\
\hline
\end{tabular}


Table 2: Effects of Preemergence Herbicides on maize germination and growth of maize at flowering

\begin{tabular}{|c|c|c|c|c|}
\hline Herbicides and rates $(\%)$ & $\begin{array}{l}\text { Germination } \\
(\%)\end{array}$ & $\begin{array}{l}\text { Survival rate } \\
\%\end{array}$ & $\begin{array}{l}\text { Plant Height } \\
(\mathrm{cm})\end{array}$ & $\begin{array}{l}\text { Stem } \\
\text { Diameter }\end{array}$ \\
\hline \multicolumn{5}{|l|}{ 3-maize force } \\
\hline 100 & $100.0 \mathrm{a}$ & $82.0 \mathrm{a}$ & $199.6 \mathrm{a}$ & $20.9 \mathrm{a}$ \\
\hline 50 & $100.0 \mathrm{a}$ & $87.0 \mathrm{a}$ & $203.0 \mathrm{a}$ & $22.9 \mathrm{a}$ \\
\hline \multicolumn{5}{|l|}{ Xtra force } \\
\hline 100 & $100.0 \mathrm{a}$ & $80.0 \mathrm{a}$ & $184.7 \mathrm{a}$ & $20.0 \mathrm{a}$ \\
\hline 50 & $95.0 \mathrm{a}$ & $81.0 \mathrm{a}$ & $198.4 \mathrm{a}$ & $21.6 a b$ \\
\hline \multicolumn{5}{|l|}{ Premaiz } \\
\hline 100 & $100.0 \mathrm{a}$ & $82.0 \mathrm{a}$ & $178.3 \mathrm{a}$ & $18.8 \mathrm{ab}$ \\
\hline 50 & $100.0 \mathrm{a}$ & $80.0 \mathrm{a}$ & $186.7 \mathrm{a}$ & $21.5 \mathrm{ab}$ \\
\hline \multicolumn{5}{|l|}{ Guard Force Solution } \\
\hline 100 & $100.0 \mathrm{a}$ & $87.0 \mathrm{a}$ & $205.9 \mathrm{a}$ & $19.5 \mathrm{ab}$ \\
\hline 50 & $100.0 \mathrm{a}$ & $87.0 \mathrm{a}$ & $202.5 \mathrm{a}$ & $21.9 \mathrm{ab}$ \\
\hline \multicolumn{5}{|l|}{ Guard force pellet } \\
\hline 100 & $100.0 \mathrm{a}$ & $89.0 \mathrm{a}$ & $206.2 \mathrm{a}$ & $21.5 \mathrm{ab}$ \\
\hline 50 & $100.0 \mathrm{a}$ & $81.0 \mathrm{a}$ & $197.3 \mathrm{a}$ & $19.4 \mathrm{ab}$ \\
\hline Atrazine 100 & $97.0 \mathrm{a}$ & $80.0 \mathrm{a}$ & $205.9 \mathrm{a}$ & $21.6 \mathrm{a}$ \\
\hline Hoe weeding & $100.0 \mathrm{a}$ & $92.0 \mathrm{a}$ & $183.1 \mathrm{a}$ & $17.7 \mathrm{a}$ \\
\hline
\end{tabular}

Table 3: Effects of Preemergence Herbicides on maize yield performance

\begin{tabular}{|c|c|c|c|c|}
\hline Herbicides and rates $(\%)$ & $\begin{array}{c}\text { Number of } \\
\text { seeds/cob }\end{array}$ & $\begin{array}{l}\text { Wt of seed } \\
\text { per cob }(\mathrm{g})\end{array}$ & $\begin{array}{l}\text { Wt of } 100 \\
\text { seeds }(\mathrm{g})\end{array}$ & $\begin{array}{c}\text { Seed yield } \\
(\mathrm{Kg} / \mathrm{ha})\end{array}$ \\
\hline \multicolumn{5}{|l|}{ 3-maize force } \\
\hline 100 & $361.8 \mathrm{a}$ & $99.3 \mathrm{a}$ & $27.3 \mathrm{a}$ & $5796.0 \mathrm{ab}$ \\
\hline 50 & $408.6 \mathrm{a}$ & $117.7 \mathrm{a}$ & $28.3 \mathrm{a}$ & $6277.3 \mathrm{ab}$ \\
\hline \multicolumn{5}{|l|}{ Xtra force } \\
\hline 100 & $346.6 \mathrm{a}$ & $105.0 \mathrm{a}$ & $29.0 \mathrm{a}$ & $5600.0 \mathrm{ab}$ \\
\hline 50 & $367.1 \mathrm{a}$ & $100.0 \mathrm{a}$ & $29.0 \mathrm{a}$ & $5349.3 \mathrm{ab}$ \\
\hline \multicolumn{5}{|l|}{ Premaiz } \\
\hline 100 & $376.4 \mathrm{a}$ & $109.0 \mathrm{a}$ & $30.7 \mathrm{a}$ & $5813.3 \mathrm{ab}$ \\
\hline 50 & $300.9 \mathrm{a}$ & $98.3 \mathrm{a}$ & $38.7 \mathrm{a}$ & $4709.3 b$ \\
\hline \multicolumn{5}{|l|}{ Guard Force Solution } \\
\hline 100 & $347.2 \mathrm{a}$ & $101.1 \mathrm{a}$ & $28.3 \mathrm{a}$ & $5392.0 \mathrm{ab}$ \\
\hline 50 & $374.4 \mathrm{a}$ & $121.7 \mathrm{a}$ & $31.7 \mathrm{a}$ & $6490.6 \mathrm{ab}$ \\
\hline \multicolumn{5}{|l|}{ Guard force pellet } \\
\hline 100 & $382.4 \mathrm{a}$ & $112.7 \mathrm{a}$ & $31.7 \mathrm{a}$ & $6010.6 \mathrm{ab}$ \\
\hline 50 & $388.7 \mathrm{a}$ & $96.3 \mathrm{a}$ & $31.0 \mathrm{a}$ & $5136.0 \mathrm{ab}$ \\
\hline Atrazine 100 & $399.3 \mathrm{a}$ & $126.7 \mathrm{a}$ & $39.0 \mathrm{a}$ & $6757.3 \mathrm{a}$ \\
\hline Hoe weeding & $338.5 \mathrm{a}$ & $103.7 \mathrm{a}$ & $38.7 \mathrm{a}$ & $5530.6 \mathrm{ab}$ \\
\hline
\end{tabular}

*Means followed by the same letters along the column are not significantly different $(\mathrm{P}=0.05)$ by DMRT 
Table 4: Effects of Preemergence Herbicides on the weed population and Biomass

\begin{tabular}{lll}
\hline \multicolumn{1}{c}{ Herbicides and rates $(\%)$} & Weed density $\left(\right.$ Unit $\left./ 0.50 \mathrm{~m}^{2}\right)$ & Weed Biomass $\left(\mathrm{g} / 0.50 \mathrm{~m}^{2}\right)$ \\
\hline 3-maize force & \\
100 & $4.0 \mathrm{~b}$ & $56.7 \mathrm{~b}$ \\
50 & $4.0 \mathrm{~b}$ & $43.4 \mathrm{~b}$ \\
Xtra force & \\
100 & $4.0 \mathrm{~b}$ & $33.4 \mathrm{~b}$ \\
50 & $4.2 \mathrm{~b}$ & $40.1 \mathrm{~b}$ \\
Premaiz & & \\
100 & $4.6 \mathrm{~b}$ & $36.6 \mathrm{~b}$ \\
50 & $4.1 \mathrm{~b}$ & $106.6 \mathrm{ab}$ \\
Guard Force Solution & & \\
100 & $5.4 \mathrm{a}$ & $53.4 \mathrm{~b}$ \\
50 & $5.5 \mathrm{a}$ & $170.0 \mathrm{a}$ \\
Guard force pellet & & \\
100 & $4.7 \mathrm{~b}$ & $33.4 \mathrm{~b}$ \\
50 & $5.4 \mathrm{a}$ & $34.1 \mathrm{~b}$ \\
Atrazine 100 & $4.0 \mathrm{~b}$ & $30.0 \mathrm{~b}$ \\
Hoe weeding & $6.2 \mathrm{a}$ & $23.4 \mathrm{~b}$ \\
*Means followed by the same letters along the column are not significantly different $(\mathrm{P}=0.05)$ by DMRT
\end{tabular}

\section{REFERENCES}

Akobundu, I.O (1987). Weed Science in the tropics: Principle and Practices. John Wiley and Son Inc. 522p

Dogan, M.N., Unay, A., Boz, O., Albay, F. (2004). Determination of optimum weed control timing in maize (Zea mays L.) Turk .J. Agric. For. 28;349-354.

Green, J.M and Owen, M.G. (2011). Herbicide Resistant Crops: Utilities and Limitations for Herbicide-resistant weed management. J. Agric. Food Chem. 59;5819-5829

Gupta, O.P (2004). Modern Weed Management (2nd ed.). Agribios Jodhpur, India p18-23

Huma, B., Hussain, M., Ning, C. and Yuesuo, Y (2019).Human benefits from maize. Sch.J. Appl. Sci. Res. 2, 2:4-7.

Ogungbile, A.O and Lagoke, S.T.O (1986). On-farm evaluation of the economy of chemical weed control in oxen-mechanized maize production in Nigeria Savanna. Tropical Pest Management 32:273

Olabode, O.S., Adesina, G.O and Babajide, P.A. (2010). Weed control efficiency of reduced Atrazine doses and its effect on soil organism in maize (zea mays L.) fields of southwestern Nigeria. Journal of Tropical Agriculture 48(1-2):52-54.

Olabode, O.S., Adesina, G.O and Olapeju, T.R. (2011). A Survey of Agricultural Chemicals available to farmers in Western Nigeria. International Journal of Agricultural Economics and Rural Development 4(1): 12-18.

Olabode, O.S., Ogunyemi S and Ajibola A.T. (2008). Evaluation of low dosage of primextra for weed control in Ogbomoso, Southern Guinea savanna of Nigerian. AFRICA: Journal of contemporary issues 6 (5): 24-29.

Paradowski, A. (2008). Alternative for atrazine in maize. Prog. plant protection/post. ochr.Ro slin. 48(2), 640-645 